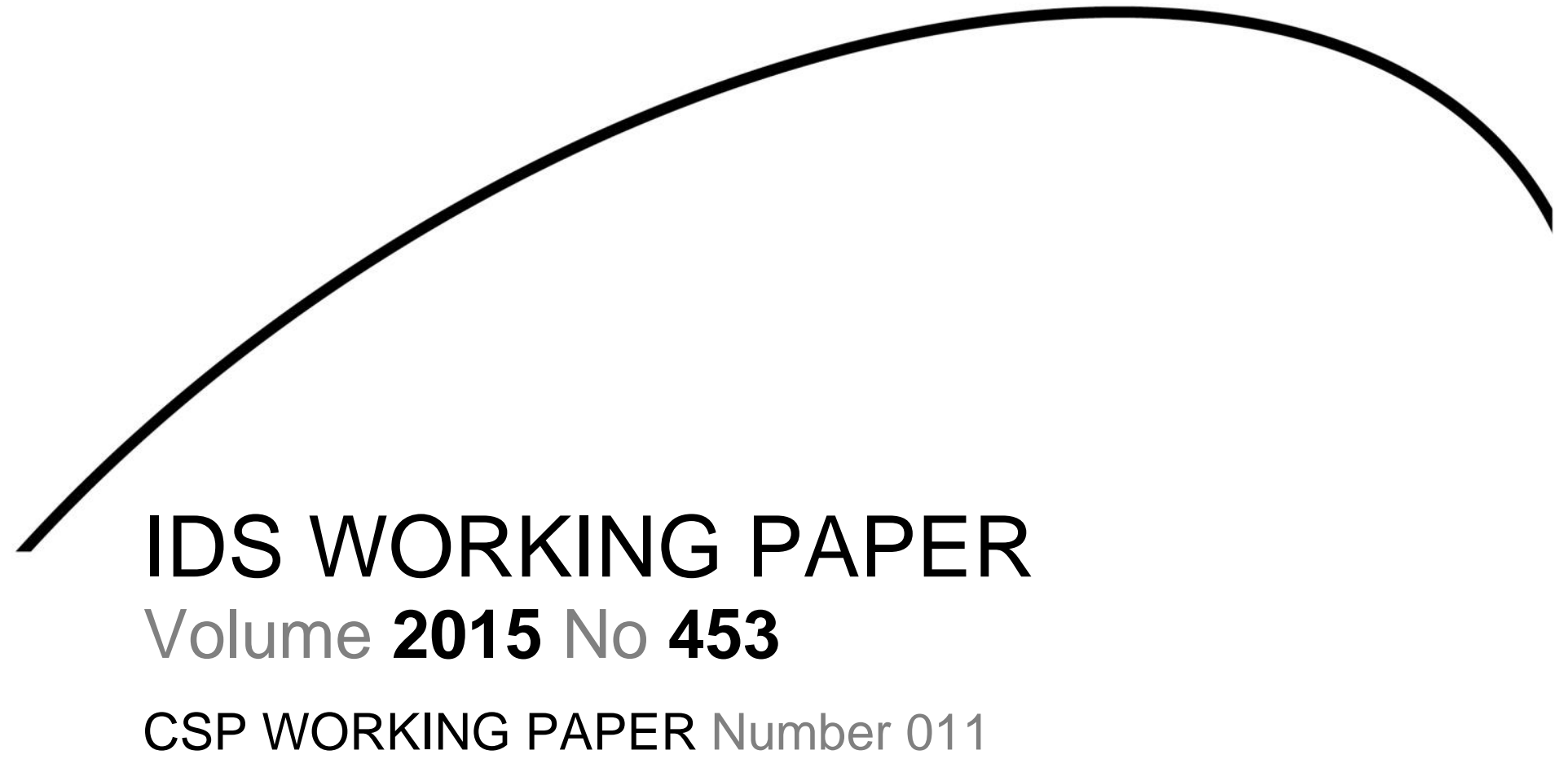

\title{
The Prospects and Politics of Social Protection Reform in Zambia
}

Maria Klara Kuss

April 2015

SP $\begin{aligned} & \text { Centre for } \\ & \text { Social Protection }\end{aligned}$ 
The Centre for Social Protection (CSP) supports a global network of partners working to mainstream social protection in development policy and encourage social protection systems and instruments that are comprehensive, long-term, sustainable and pro-poor. We produce research on conceptual approaches; design issues, including delivery, targeting and affordability; and impacts of different social protection initiatives.

Email: socialprotection@ids.ac.uk

Web: http://www.ids.ac.uk/idsresearch/centre-for-social-protection

\section{CSP WP011}

CSP Working Paper series editor: Stephen Devereux

The Prospects and Politics of Social Protection Reform in Zambia

Maria Klara Kuss

First published by the Institute of Development Studies in April 2015

IDS Working Paper 453

(C) Institute of Development Studies 2015

ISSN: 2040-0209 ISBN: 978-1-78118-227-7

A catalogue record for this publication is available from the British Library.

All rights reserved. Reproduction, copy, transmission, or translation of any part of this publication may be made only under the following conditions:

- with the prior permission of the publisher; or

- with a licence from the Copyright Licensing Agency Ltd., 90 Tottenham Court Road, London W1P 9HE, UK,

or from another national licensing agency; or

- under the terms set out below.

This publication is copyright, but may be reproduced by any method without fee for teaching or nonprofit purposes, but not for resale. Formal permission is required for all such uses, but normally will be granted immediately. For copying in any other circumstances, or for reuse in other publications, or for translation or adaptation, prior written permission must be obtained from the publisher and a fee may be payable.

Available from:

Communications and Engagement Unit, Institute of Development Studies, Brighton BN1 9RE, UK

Tel: +44 (0) 1273915637 Fax: +44 (0) 1273621202

E-mail: bookshop@ids.ac.uk

Web: www.ids.ac.uk/publications

IDS is a charitable company limited by guarantee and registered in England (No. 877338) 


\title{
The Prospects and Politics of Social Protection Reform in Zambia
}

\author{
Maria Klara Kuss
}

\section{Summary}

This paper analyses the prospects for social protection reform in Zambia under the 'pro-poor' government of the Patriotic Front (PF). The paper argues that the PF has been changing the development policy arena in ways that may modify domestic political structures providing more rights-based benefits especially for the extreme poor and vulnerable. It further reveals that the persistence of the clientelistic dynamics of state-society relations and weak civil society organisations inhibit the expression of demands for formal social protection by poor people. It concludes that because the social protection reform is supply-, rather than demand-driven, its progress depends on the extent to which the government is motivated to sustain the provision of social protection in the long-run.

Keywords: Politics of Social Protection; Social Cash transfers; Clientelism; Sub-Saharan Africa; Zambia

Maria Klara Kuss specialises in Social Policy and Social Protection, Governance and Gender mainstreaming. She has worked with many international organisations such as UNICEF, OECD, UNIFEM and GIZ conducting inter-disciplinary, policy-relevant research, gender analysis, policy analysis and impact assessments. More recently, Maria has been a Research Officer in the Vulnerability and Poverty Reduction team at the IDS and a member of the Centre for Social Protection. Her work has concentrated on a UNICEF funded project that examines the views, experiences and perceptions of Social Cash Transfer Programme recipients and their communities in Zambia. With an academic background in Social Work and Governance \& Development, her research interests bridge the fields of social and political science with a strong focus on social protection and state-society relations in subSaharan Africa. Currently, Maria is undertaking her PhD at the United Nation UniversityMERIT's Maastricht Graduate School of Governance. 


\section{Contents}

Summary 3

Acknowledgements

Acronyms 5

Introduction

1. The demand for social protection in Zambia 7

1.1 The demand and influence of the urban and the rural population 7

1.2 The demand for social protection: civil society organisations and the
influence of cooperating partners

2. The supply of social protection: changes under the PF government 12

2.1 From a lack of commitment to fostering the policy environment for social protection

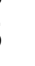

(1)

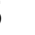

2.2 From market interventions to more fiscal space for social protection 14

2.3 From patrimonial benefits to formal social protection 15

3. Conclusion 17

$\begin{array}{ll}\text { References } & 18\end{array}$

Tables

Table 1 Budget allocation for social spending (health, education, social protection) 


\section{Acknowledgements}

This paper has benefited greatly from feedback and comments from a wide range of experts and interview partners to whom I am very grateful, in particular: Allister McGregor (IDS); Anuradha Joshi (IDS); Jennifer Leavy (University of East Anglia); Robin Luckham (IDS); Daniel Kumitz (Independent Social Protection Consultant Zambia/FES Zambia); and Miguel A. Rivera-Quiñones (IDS). I also wish to thank the two reviewers, Stephen Devereux (IDS) and Esther Schüring (Bonn-Rhein-Sieg University of Applied Sciences) for their helpful and insightful comments. Financial support from the Swiss Agency for Development and Cooperation (SDC) is gratefully acknowledged. Further comments are welcome and can be sent tom.kuss@ids.ac.uk.

\section{Acronyms}

$\begin{array}{ll}\text { CSO } & \text { Central Statistical Office } \\ \text { CSPR } & \text { Civil Society for Poverty Reduction } \\ \text { DFID } & \text { UK Department for International Development } \\ \text { FES } & \text { Friedrich Ebert Foundation } \\ \text { FISP } & \text { Farmers Input Support Programme } \\ \text { GRZ } & \text { Government of the Republic of Zambia } \\ \text { GTZ } & \text { German Development Cooperation } \\ \text { HLPE } & \text { High Level Panel of Experts } \\ \text { ILO } & \text { International Labour Organization } \\ \text { JCTR } & \text { Jesuit Centre for Theological Reflection } \\ \text { KR } & \text { Kwacha rebased } \\ \text { LGAZ } & \text { Zambia and the Local Government Association of Zambia } \\ \text { MCDMCH } & \text { Ministry of Community Development Mother and Child Health } \\ \text { MLSS } & \text { Ministry of Labour and Social Security } \\ \text { MMD } & \text { Movement for Multiparty Democracy } \\ \text { PF } & \text { Patriotic Front } \\ \text { PSP } & \text { Platform for Social Protection } \\ \text { SNDP } & \text { Sixth National Development Plan } \\ \text { UNICEF } & \text { United Nations Children's Fund } \\ \text { UNZA } & \text { University of Zambia } \\ \text { WFP } & \text { United Nations World Food Programme } \\ & \end{array}$




\section{Introduction}

Social protection reform in any country is inherently political. Who demands what from whom? Who gets how much? And what are the drivers for the supply of social protection? The answers depend upon a variety of political dynamics and small variations in the political structures can have large impacts upon social protection outcomes (Barrientos and Pellissery, 2012). In Zambia, the last general election in 2011 produced a major political change when the Movement for Multiparty Democracy (MMD), which had been in office for two decades, was defeated by the Patriotic Front (PF). The PF promised Zambians 'pro-poor change' as well as 'more jobs, lower taxes, and more money in the pocket'. It is early days and a comprehensive assessment of the impacts of the PF government has not yet been possible. However, it is possible to examine the changes that are already underway in the social protection sector to assess whether these are likely to be more beneficial for the extreme poor and vulnerable. In order to do this, this paper analyses the 'supply' and 'demand' of social protection in Zambia at this time.

The distinction between policy demand and supply reflects two main dynamics of political decision-making that can provoke any public policy reform. Demand-driven reforms respond to citizens, who express their needs through elections, complaints, protests or lobbying (Goetz and Gaventa 2001). Supply-driven reforms are motivated by state actors to increase social stability, communicate a benevolent image or gain credibility (Pelham 2007). Reforms driven by any combination of these dynamics can shift the benefits in any direction: more to the poor or more to already powerful elites. The outcomes depend on the actors involved, their motives and the power relationships between them (Hickey 2007). In Zambia key sets of actors on the demand side include urban and rural dwellers, opposition parties and lobby groups; on the supply side are international donors, the Head of State and Cabinet Ministers.

Bargaining among these actors can follow informal (e.g. clientelistic) or formal (e.g. rightsbased) rules (Kitschelt and Wilkinson 2007; Weber 1946).

- Under clientelistic rules patrons distribute social protection to loyal clients in direct exchange for their political support (Kitschelt and Wilkinson 2007). Hence, targeting of such programmes is based on political strategic preferences (ibid). Further, the provision of these programmes often fluctuate which may be reflected in short-term strategies as the programmes are utilised strategically to encourage or reward clients (ibid and Rakner and Van de Walle 2009). This typically requires a delivery mechanism that has limited transparency and a weak monitoring and accountability system (Kitschelt and Wilkinson 2007). These types of programmes will be referred to as patrimonial programmes.

- In contrast, under rights-based rules, the supply of social protection is independent from the party affiliation of the recipient and grounded in a right to social protection that is legally enforceable by recipients (Devereux and McGregor 2014; Munro 2007). Hence, the government distributes benefits to citizens based on formal eligibility criteria (Kitschelt and Wilkinson 2007'). Furthermore the continuity of the provision is based on formal graduation criteria and hence predictable for beneficiaries (ibid). The delivery mechanism of the programme limits the utilisation of the benefit for patrimonial gains by a strong monitoring and accountability system that enhances transparency and oversight (ibid). These types of programmes will be referred to as formal programmes. 
The analysis that is provided here is guided by a set of 13 key informant interviews with informants from the Ministry of Community Development Mother and Child Health (MCDMCH) and the Ministry of Labour and Social Security (MLSS); civil society organisations such as the Platform for Social Protection (PSP), the Friedrich Ebert Foundation (FES) Zambia and the Local Government Association of Zambia (LGAZ); cooperating partners such as the United Nations World Food Programme (WFP) Zambia, the United Nations Children's Fund (UNICEF), and the UK Department for International Development (DFID); and the University of Zambia (UNZA). Key themes explored were the organisational set up of social protection and cash transfers in Zambia; the currency of discussion of social protection under the PF government; the changes in the social sector under the PF; and the status quo of the social protection policy. The qualitative work was conducted in Lusaka during late May 2013. The analysis has been further bolstered by follow-up email consultations with key informants as well as reviews of secondary documentation, contemporary commentary and new material as it emerged.

Drawing on the experience of Zambia as a case study, this paper analyses the prospects for social protection reform under the PF government. This paper understands social protection as a set of policy instruments that address poverty and vulnerability, through the provision of social assistance, social insurance and social inclusion (HLPE 2012:11). The paper is organised in three main sections: Section 1 begins with an analysis of the demand side for social protection in rural and urban Zambia before and after the electoral change. This reveals that the persistence of clientelistic dynamics and weak civil society organisations inhibit the expression of demands for formal social protection by poor people. Section 2 then turns to analyse the make-up of the supply side for social protection under the PF government. It argues that the PF is modifying domestic political structures in ways that may facilitate the provision of rights-based social protection. Section 3 concludes that because the social protection reform is supply-, rather than demand-driven, its progress depends on the extent to which the government is motivated to sustain the supply of social protection in the long-run.

\section{The demand for social protection in Zambia}

The demand for social protection by different groups within society reflects their different (sometimes conflicting) needs (Hickey 2007; Goetz and Gaventa 2001). Different groups also can have different opportunities to express their needs and can ultimately provoke different social protection reforms (Hickey 2007; Goetz and Gaventa 2001). This section explores how different groups within the Zambian society such as urban and rural dwellers are able to express their demands and influence policy-making. Furthermore, it looks at how they are able to receive support from a range of influential bodies, including political parties and civil society organisations. Unsurprisingly it reveals that the poorest and most vulnerable people in Zambia (e.g. subsistence farmers, children, persons with disabilities or older persons) struggle to voice their demands because those that might represent them either have no 'real' interest in expressing their needs or have only weak political leverage.

\subsection{The demand and influence of the urban and the rural population}

In Zambia the interest in social protection differs markedly between the rural and urban poor because of different life circumstances, needs and state-relations. With a relatively high level of urbanisation by African standards, standing at 35\% in 2006 (CSO 2011; Cheeseman and Larmer 2013), the urban/rural divide has massively influenced the political playing field in Zambia. In recent years, expanding urban poverty and declining formal employment posed a 
significant threat to the stability of the former government and increased the urban influence on policy-making, peaking in the electoral change in 2011 (Resnick 2010; Helle and Rakner 2012; Ochieng' Opalo 2012).

Apart from favourable conditions for influencing policy-making, people in urban areas on average also benefit from higher standards of living than in the countryside. Urban poverty levels are less than half that obtaining in rural areas. For 2010, the Central Statistical Office (CSO 2011) estimated that $28 \%$ of urban dwellers live in poverty and $13 \%$ in extreme poverty; while in rural areas $78 \%$ of the population live in poverty and $58 \%$ in extreme poverty. The economic activities in the city are substantially more diverse than those in the countryside (World Bank 2007). According to the World Bank (2013: 17), based on the 2008 Labour Force Survey the vast majority of urban dwellers (74\%) engage in a variety of different informal sector activities such as petty trading or unskilled labour; while the majority of rural residents overwhelming rely on semi-subsistence agriculture $\left(65 \%{ }^{2}\right)$. Also consumption patterns in urban areas are more diverse than in rural areas (World Bank 2013). For instance, urban residents spent around 39\% of household income on food-items, $31 \%$ on housing and $7 \%$ on transport (ibid: 25 ). In contrast, rural residents spent the majority of their income on food items (65\%), only $16 \%$ on housing and $3.5 \%$ on transport (ibid: 25 ). Devereux and Sabates-Wheeler (2004) argue that different living conditions involve different economic problems or livelihood risks and shocks and require different social protection responses. People in urban Zambia might need programmes which facilitate formal employment, protect informal workers against work injuries, or protect formal workers against exploitation or job losses. Rural dwellers might need food or cash transfers to provide subsistence, safety nets in case of environmental shocks, or agricultural input subsidies to facilitate cultivation.

The different needs and living standards of people in urban and rural areas are reflected in different party affiliations and political support (Cheeseman and Paget 2011; Resnick 2010; Helle and Rakner 2012). People in rural areas tend to support parties that appeal on the basis of patronage. For instance, Rakner (2012) notes that during the last general election in 2011, the MMD government largely deployed patronage strategies to appeal to its rural support base. Helle and Rakner (2012) observed that the MMD had already in the previous elections in 2006 and 2008 concentrated on vote-buying in rural areas. In particular, agricultural subsidies were used as a tool to construct and sustain clientelistic networks in rural areas (Mason and Ricker-Gilbert 2013; Banful 2010; Devereux and White 2010).

Clientelistic networks are typically set up as a support pyramid that consists of the clients (e.g. rural electorate) at the ground; brokers in the middle; and the incumbent at the top (Kitschelt and Wilkinson 2007). This hierarchy determines the distribution of benefits from one level to the next in exchange for political support. In Zambia, it is argued that the clientelistic structure of state-society relations - especially in rural areas - emanates from the British colonial administration of indirect rule (Harland 2014; Mamdani 1996). This represented a low cost local governance system that authorised traditional Chiefs (brokers) to rule their rural constituencies in exchange for order, peace and taxes. Rural dwellers were accountable to their Chiefs and Chiefs to the British Colonial Officers (Acemoglu et al. 2013). While direct governance, through the establishment of a formal local government system, expanded to rural areas after independence, services remained limited especially in more isolated rural areas (Duncan et al. 2003). Therefore, some Chiefs could yet maintain their position as middlemen between politicians and the rural electorate by facilitating the delivery of benefits from the central government to rural areas in return for political support (Baldwin 2013; Erdmann and Simuntany 2003). Further, as noted by Van Donge (1998), public servants also became influential lower to middle level brokers in Zambia's clientelist system. 
Within such a system, the policy-influence of (rural) people at the base on the support hierarchy remains limited (Duncan et al. 2003; Barrientos et al. 2005). Schüring and LawsonMcDowall (2011) note that this system offers little space for people to participate in policymaking. Goetz and Gaventa (2001) argue that the provision of benefits in such a system relies on reciprocity. Hence, people receive services based on favours and not on rights (Goetz and Gaventa 2001). Patrimonial demands trigger responses by patrons targeted at a particular requesting client or group of clients (Kitschelt and Wilkinson 2007). The system thus excludes the poor and vulnerable outside the patrimonial network (e.g. poor and vulnerable people in urban areas) (Chabal and Daloz 1999). This again influences how people demand services because a minimum assumption of social rights constitutes a precondition for demanding rights-based social protection (Goetz and Gaventa 2001; Barrientos et al. 2005). Instead, people expect that they will receive services only if they are part of the patrimonial support base and therefore adapt their behaviour in order to access services (Cheeseman and Paget 2011). If they took a rights-based stand instead of aligning themselves with a local patron, they would risk being excluded from accessing services when a rival local patron came to power (ibid). Hence, patrimonial state-society functioning limits rights-based demands. Furthermore, patrimonial functioning of state-society relations conflicts with the incentives for rights-based policies (e.g. an entitlement to social protection) as it would make people at the base of the support hierarchy more politically autonomous and would hence undermine existing power structures (Harland 2011:8). It also incentivises the adoption of short-term strategies instead of wide-reaching rights-based appeals (Rakner and Van de Walle 2009). But the system, as noted by Magaloni (2006) and Helle and Rakner (2012), appears favourable for incumbents because it creates a loyal class of rural poor.

In the past, rural constituencies predominantly voted for the MMD, who largely employed patronage based strategies by misusing state resources (Cheeseman and Paget 2011; Ochieng' Opalo 2012). In contrast, the urban poor appealed to the populist party leader Michael Sata of the PF (Rakner 2012; Cheeseman and Paget 2011). According to Resnick (2010:8), the urban population under the MMD government suffered from the effects of the economic structural adjustment reforms - such as the removal of currency controls and price subsidies, greater economic austerity, privatisation and trade liberalisation. This, coupled with rapid urbanisation ${ }^{3}$, impacted on the living costs, working conditions and employment opportunities of urban dwellers (Resnick 2010; Cheeseman and Hinfelaar 2009). Hence, as argued by Cheeseman and Paget (2011) the PF has established more direct linkages with urban voters - without a middleman who negotiates relations - as well as appeared to be genuinely committed to generate rights-based policies in order to improve the situation of the urban poor.

The PF also employed ethnic strategies to mobilise support as the votes of the urban electorate - with only $35 \%$ of the Zambian population living in urban areas (CSO 2011) would not have been sufficient to gain a national majority. According to Resnick (2010), the PF's policy statements however failed to respond to or even opposed the needs of the majority of the rural electorate (for instance the demand for lower food prices by the urban population stands contrary to the rural demand for higher incomes from agriculture). As an alternative route to gathering votes Sata employed an ethno-linguistic strategy entering into powerful patron-client networks (Cheeseman and Paget 2011). He mobilised his own ethnic group, the Bemba that constitute $32 \%$ of Zambia's rural population, one of the biggest ethnic groups in the country mainly residing in the Copperbelt, Luapula, and Northern Province (Resnick 2010; Cheeseman and Hinfelaar 2009). It also comprised one of the main groups of the central committee of the PF (Jakusch and Naumann 2011) and helped the PF to finally win the general elections in 2011, after three failed attempts in 2001, 2006 and 2008 (Cheeseman and Larmer 2013).

3 For instance in the 1990s the population of the capital Lusaka grew at a rate of 3.3 per cent per annum (CSO 2003). 
Since the PF assumed office, there are signs that the voice of the urban poor has lost its unity and ultimately the strength to pressure 'their' government. ${ }^{4}$ So far, it appears that some urban residents have benefited to some extent from policy changes introduced by the PF (e.g. the increase of public sector salaries by $200 \%$ or the increase of the minimum wage in the private sector) while others have lost out (e.g. the raising of the retirement age from 55 to 65 and the removal of maize and fuel subsidies). ${ }^{5}$ Cheeseman and Paget (2011) also note that in fact the PF's internal organisation contains few mechanisms to ensure that their constituencies continue to be represented. In fact they argue that 'the poor and unemployed people that the party is committed to defending have no role to play in the way the party makes decisions' (ibid: 10).

Moreover, the PF has also been accused of strategically weakening opposition parties (Freedom House 2013) in order to limit their policy influence and consolidate PF power. For instance, the PF triggered several by-elections by sub-dividing districts in which the PF had had the majority vote 6 . They also encouraged MMD parliament members to join the ruling party and receive jobs within the government cabinet ${ }^{7}$ or nullified some of the election results in which the opposition had gained seats on the grounds of electoral malpractices (ibid.). The PF gained only $40 \%$ of seats in parliament in the 2011 general election, with which it formed a minority government ${ }^{8}$ (Electoral Commission of Zambia 2011), but only two years later, as a result of its manoeuvres, the PF had dramatically increased its seats in parliament to the extent that it required only two more seats to secure an absolute majority (Motsamai 2013). This, as noted by Cheeseman and Paget (2011:111), has diluted the coherence of the party and diffuses the rights-based and democratic party image. It also points to the risk that over time the PF may change its direction and follow similar (clientelistic) strategies as the MMD to gain political support in the next elections (ibid).

\subsection{The demand for social protection: civil society organisations and the influence of cooperating partners}

Civil society organisations are formed voluntarily by members of society to protect or extend particular interests, values or identities (Manor 1999). In Zambia, there are only a few civil society organisations in the social protection sector representing the extreme poor and vulnerable people in urban and rural areas (Barrientos et al. 2005). At national level, the most important civil society organisations are the Platform for Social Protection (PSP), the Jesuit Centre for Theological Reflection (JCTR) and the Civil Society for Poverty Reduction (CSPR). ${ }^{9}$ Their influence on policy-making depends on the quality of spaces to participate in policy-making (Gaventa 2004). The political system can undercut the influence of civil society organisations if their agendas are not in line with prevailing political agendas or the patronage systems (Goetz and Gaventa 2001).

While Zambian civil society organisations are invited to participate in various 'spaces' to influence policy making (such as the Social Protection Sector Advisory Group; the Technical Working Groups of the Joint Assistance Strategy or the National Development Plans), they are designated a consultative role. ${ }^{10}$ Key informants reported that often suggestions made by

Interview Cooperating Partner, Lusaka, May 2013.

Interview Cooperating Partner, Lusaka, May 2013.

Furthermore, the PF government claims that the district creation is intended to bring services closer to the people. This again mobilises the votes. But, yet, in the absence of an adequate budget to create district administration, most new districts are not functional (E-mail consultation Cooperating Partner, July 2013).

$7 \quad$ The PF practices to 'buy off' members of parliament created one of the biggest cabinets in the history of Zambia with 70 ministers and deputy ministers in 2013 (Zambian Watchdog 2013). While $40 \%$ of the seats in parliament were allocated to the PF, $36.7 \%$ were filled by the former ruling party MMD, $18.7 \%$ by UPND/UDA and the remaining seats by smaller parties (Electoral Commission 2011).

Interview Social Protection Consultant, Lusaka, May 2013.

Interview Civil Society Organisation, Lusaka, May 2013. 
civil society organisations in these 'invited spaces' were not taken seriously by the government. ${ }^{11}$ Schüring and Lawson-McDowall (2011:15) argue that in practice, politicians know that civil society organisations often do not represent 'large blocs of easily rallied and irate voters'; but the rural electorate which can be bought off by patrimonial benefits.

Further it is also challenging for civil society organisations to represent the demands of the extremely poor people especially in rural areas. ${ }^{12}$ The poor regional distribution of civil society organisations, with most operating in urban areas and having weak grassroots structures reflects a lack of representation of the demand of rural residents. ${ }^{13}$ Barrientos et al. (2005:45) argue that community activism may have increased in Zambia in recent years, but only a few community-based organisations include the destitute or poorest of the poor. Further, Schüring and Lawson-McDowall (2011) and Petrauskis (2007) note that prevalent organisations in the sector of social protection in rural areas are merely non-government organisations. These organisations focus on providing services (e.g. home-based care) instead of lobbying for their clients and influencing improved services provided by the government (Schüring and Lawson-McDowall 2011). The establishment of such stateindependent delivery structures for social protection however further undermines the demand for social protection by the population towards the state as it deflects the attention of the recipients of public services (Hickey 2007; De Haan et al. 2002).

Another challenge reported by key informants is the ability of organisations to mobilise resources to support their demands. ${ }^{14}$ Most civil society organisations are almost entirely dependent on funding from external sources through donors or even opposition parties. ${ }^{15}$ This results in a lack of autonomy to develop their own strategies and objectives or to advocate for social protection instruments that are not so popular with aid donors - such as the Public Welfare Assistance Scheme. ${ }^{16}$ Civil society organisations increasingly need to compete for funding with other civil society organisations which makes it more difficult to focus on the day to day work of advocating for the poor. ${ }^{17}$ Schüring and Lawson-McDowall (2011) also note that on an international scale in recent years there has been a significant decline in funding that emerged from the donors' decisions to turn away from funding civil society organisations and towards government budget support. Prizzon (2013) estimates that in Zambia traditional development assistance has nearly halved over the last decade, from KR7,834 million (US $\$ 1,500$ million) in 2000 to KR445 million (US\$852 million) in 2010 in real terms.

This section has looked at the demand side for social protection in Zambia under the MMD government and the PF government. It revealed that people in rural areas, where extreme poverty is prevalent, have had, at least under the MMD government, limited policy influence due to the prevailing clientelistic state-society functioning. Within this system benefits are targeted at clients in reciprocal exchange of political support. This excludes the poor and vulnerable outside the patrimonial network. Furthermore clientelistic state-society functioning generates short-term benefits that maintain existing power relations. Beyond that it limits rights-based demands as voters expect clientelistic rewards. Poor urban dwellers have somehow had more leverage on policy making especially prior to the national general elections of 2011 when the PF embodied the demands of the urban poor in its populist promises. The PF also employed an ethnic strategy to gain support among the rural

Interview Civil Society Organisation, Lusaka, May 2013.

Interview Public Servant, Lusaka, May 2013.

Interview Public Servant, Lusaka, May 2013.

Interview Civil Society Organisation, Lusaka, May 2013; and interview UNZA, Lusaka, May 2013.

Interview Civil Society Organisation, Lusaka, May 2013; and interview UNZA, Lusaka, May 2013.

Interview Civil Society Organisation, Lusaka, May 2013.

Interview Civil Society Organisation, Lusaka, May 2013; and interview UNZA, Lusaka, May 2013. 
population, targeted at the Bemba. This dual strategy resulted in the electoral change in 2011.

But since assuming office and fulfilling some electoral pledges, the demands of the urban poor appears somehow diffused as some benefited from the PF's policy changes while others did not. Further, given that the former voice of the urban poor is now in power, the capacity to voice demands appears to have deteriorated. Moreover, the PF have yet largely failed to institutionalise the representation of their constituencies. The voice of the people is further undermined by the PF's strategy to strategically weaken its opposition parties through rather 'undemocratic' means. Civil society organisations also struggle to represent the demands of the poor and vulnerable and to pressure the government to respond to their demands as they appear to have only limited leverage on policy-making. Representation appears to focus rather on urban centres; while in rural areas grassroots structures are weak and non-government organisations prevail. These organisations however may create parallel social protection delivery systems which further undermine the demand for formal social protection. Therefore this section concludes that the poorest and most vulnerable people especially in rural areas struggle to demand formal social protection from the government. The next section sheds light on the provision of social protection for the poor in Zambia and the changes in the social protection sector implemented by the government of the PF.

\section{The supply of social protection: changes under the PF government}

This section compares the provision of social protection under the MMD government and the PF government. While under the MMD the social protection agenda was heavily donordriven, the PF has taken more vigorous steps towards the development of a social protection policy. It argues that the PF government has been modifying the social protection sector in ways that shift more benefits to the extreme poor and vulnerable. The PF also has created more fiscal space for social protection targeted at the extreme poor and vulnerable and drastically increased social sector spending. Further, the PF has also shown more support for formal social protection programmes (such as social cash transfer programmes) while also increasing transparency of programmes (such as the Farmers Input Support Programme, FISP) that were previously used as patrimonial transfers.

\subsection{From a lack of commitment to fostering the policy environment for social protection}

The MMD government was often accused of a lack of commitment towards rights-based social protection (Schüring and Lawson-McDowall 2011). Initiatives fostering the social protection agenda were often heavily driven by cooperating partners (ibid), namely the World Bank, the International Labour Organization (ILO), the German Development Cooperation $(G T Z)^{18}$, the UK Department for International Development (DFID) or the United Nations Children's Fund (UNICEF) (Barrientos et al. 2005). They employed different strategies to push the MMD government to foster the social protection agenda. According to Schüring and Lawson-McDowall (2011), cooperating partners demanded social protection in invited spaces of policy-making such as the sector advisory and technical working groups. They organised visits for members of parliament, ministers, and public servants to see the social protection programme in practice 'with own eyes' (Jackson et al. 2011). They conducted trainings and workshops for members of parliament to emphasise the link between growth and social protection. ${ }^{19}$ They also conducted several assessments to create evidence for the positive

Now German Implementing Agency for Development Cooperation (GIZ).

Interview Civil Society Organisation, Lusaka, May 2013. 
impact of the programme (Schüring and Lawson-McDowall 2011). As noted earlier, donors also contributed towards the funding of civil society organisations in order to foster the social protection agenda.

But the MMD remained reluctant to fully commit to rights-based social protection (NinoZarazua et al. 2011; Barrientos et al. 2005). Hence, when the PF assumed office, there was no social protection policy, no constitutional ${ }^{20}$ entitlement; weak coordination of programmes; and only an expired draft social protection strategy that was never endorsed by the Zambian Cabinet (World Bank 2013). Formal social protection programmes - such as social cash transfer schemes - were often perceived as 'donor-babies'21, because cooperating partners largely formulated and financed these instruments (Schüring and Lawson-McDowall 2011; Barrientos et al. 2005). Nino-Zarazua et al. (2011:167) argue that these programmes, therefore, rather reflect the direct interest of donors instead of a considered strategy by the government. This was reflected in an uncertain domestic political support for formal programmes and precarious long term sustainability (ibid.). A small sign of progress in the social protection sector under the MMD government was the incorporation of the objectives of the draft social protection strategy in the Fifth and Sixth National Development Plans.

The PF government has begun to address formal social protection more 'deliberatively'. ${ }^{22}$ While their constituency has been largely constituted by the urban electorate with their demand for job creation, better employment conditions and lower living costs, the PF has also advocated for the extreme poor and vulnerable. In their Manifesto, they promised Zambians that they would 'pursue all possible means to ensure a decent and dignified life for all citizens, especially those who are unable to create security and livelihoods for themselves' (PF 2011: 21). Since assuming office, the PF has reviewed the Sixth National Development Plan (SNDP) in order to align it with its aspiration to shift more benefits to the poor and vulnerable. The reviewed plan gives social protection more importance and moves it from being a support area to one of the key investment sectors (GRZ 2013). The new version spells out the specific target groups and adds a focus on persons with disability. It also extends the strategies and increases the budget allocation for social protection. The new version also reconfirms the promise to 'create an enabling policy environment for the establishment of a [...] national social protection system [...] and improving coordination in the sector [...].' (GRZ 2013: 140).

Yet the PF has taken 'more vigorous steps towards the establishment of a sound social protection policy'23. In their Manifesto they promised 'to adopt a comprehensive social protection policy, which will guarantee all citizens access to basic services, and provide additional support to those who face special challenges in meeting their basic needs' (PF 2011:21). This policy is a precondition for the development of a Social Protection Act which would legally entitle Zambians to social protection. ${ }^{24}$ The PF has already carried out extensive assessments on delivery, impact and finance that guide the social protection policy development. They further set up a technical working group responsible for the development of a social protection policy. This group consists of key representatives of the Ministry of Community Development Mother and Child Health (MCDMCH), the Ministry of Labour and Social Security (MLSS), cooperating partners and civil society organisations. ${ }^{25}$ In February 2014, the Cabinet began a process of approving the National Social Protection Policy. This

20 Zambia's constitution is currently under reform. The final version should have been submitted by September 2012 (Freedom house 2013). But the process has been delayed and the new constitution was only published in draft form in October 2014 (Zambian Economist 2014).

$21 \quad$ Interview Civil Society Organisation, Lusaka, May 2013; interview UNZA, Lusaka, May 2013; and interview Public Servant, Lusaka, May 2013.

Interview Cooperating Partner, Lusaka, May 2013.

Interview Public Servant, Lusaka, May 2013.

Interview Public Servant, Lusaka, May 2013.

Interview Social Protection Consultant, Lusaka, May 2013. 
policy was passed in June 2014 and is now being rolled out at speed. This might be exemplified by the massive scale up of social cash transfer programmes in 2014 (see section 2.3).

\subsection{From market interventions to more fiscal space for social protection}

Economic growth and market interventions were deployed as key strategies to alleviate poverty under the MMD government. ${ }^{26}$ But despite robust economic growth ${ }^{27}$ and large public transfers in the last years, Zambia's poverty rate remained stubbornly high (World Bank 2013). According to the Central Statistical Office (CSO 2011) $60 \%$ of the population live in poverty and $39 \%$ in extreme poverty. For instance, the MMD government introduced heavy fuel and maize miller subsidies as measures to combat poverty and mitigate the effects of the international oil and food crises (Chapoto 2012; CUTS International 2013). But the benefits of these transfers, as argued by the PF, have not been shared equally among the population, as the programmes directly target the already wealthy commercial millers, vehicle owners and industries and not the poor (Statehouse 2013). Worse still, the maize miller subsidy failed to reduce the prices of maize meal for the consumers; instead the benefit remained with a few selected millers who purchased subsidised maize grains (Chapoto 2012; Kuteya and Jayne 2012). The subsidies also restricted social sector spending (e.g. on well-targeted social protection programmes) (DFID 2012). For instance, according to a report produced by CUTS International, the fuel subsidy cost KR179 million (US\$34.3 million) in 2009 and with rising international prices, the subsidy escalated to KR1,166 million (US\$223.3 million) in 2013. CUTS International (2013) indicates that this exceeds the budget allocation for social protection ${ }^{28}$ by $31 \%$ (CUTS 2013:17). ${ }^{29}$

The PF government emphasises health, education and social protection as responses to poverty and vulnerability (PF 2011). On taking up office the PF also abolished the fuel and maize miller subsidies. It is argued that in the long term the policy change will increase fiscal discipline and the fiscal space for investment in the social sector (DFID 2012). In the short term, however the removal of these subsidies is perceived to increase fuel and maize meal prices which impairs on both urban and rural households. ${ }^{30}$ High petrol prices are seen to impact directly on urban households as they rely more heavily on transport than rural households. ${ }^{31}$ Indirectly however rural purchasers are affected by higher food prices in rural areas as a result of increased transport costs (Kuteya and Sitko 2014).

To mitigate potential adverse effects of the subsidy removals and reduce poverty, especially in rural areas, the PF has promised to increase social sector spending (Statehouse 2013). The 2014 budget statement confirmed the PF's intention and reflected higher levels of spending on health, education and social protection (Table 1). In 2011, the MMD had allocated KR8,086 million (US\$1,556 million, $29.20 \%$ of the entire budget) to these sectors; in 2012 the PF increased the sector allocation by $2.40 \%$ to KR10,157 million (US\$1,955 million, $31.60 \%$ of the entire budget); in 2014 the PF almost doubled the real budget allocation 2011 from KR8,086 million (US\$1,548 million) to KR14,018 million (US\$2,698 million), which reflects $32.90 \%$ of the entire budget.

Interview Cooperating Partner, Lusaka, May 2013.

In 2010, the economy grew at a rate of 7.6\% (World Bank 2013).

This includes the Public Service Pension Fund as well as various safety nets such as the Public Welfare Assistance Scheme and social cash transfers (GRZ 2012a).

Estimations based on the Budget Speech 2013 (GRZ 2012a).

Interview Cooperating Partner, Lusaka, May 2013; and interview Public Servant, Lusaka, May 2013.

Interview Civil Society Organisation, Lusaka, May 2013. 
Table 1 Budget allocation for social spending (health, education, social protection)

\begin{tabular}{|l|r|r|r|r|r|r|}
\hline & \multicolumn{1}{|c|}{$\begin{array}{c}\text { 2011 } \\
\text { (in KR } \\
\text { million) }\end{array}$} & \% of Budget & $\begin{array}{c}\text { 2012 } \\
\text { (in KR } \\
\text { million) }\end{array}$ & \% of Budget & \multicolumn{1}{c|}{$\begin{array}{c}\text { 2013 } \\
\text { (in KR } \\
\text { million) }\end{array}$} & \% of Budget \\
\hline Health & $2,579.90$ & $9.30 \%$ & $3,638.10$ & $11.30 \%$ & $4,228.40$ & $9.90 \%$ \\
\hline Education & $4,850.50$ & $17.50 \%$ & $5,626.80$ & $17.50 \%$ & $8,607.00$ & $20.20 \%$ \\
\hline Social Protection & 655.60 & $2.40 \%$ & 892.20 & $2.80 \%$ & $1,183.00$ & $2.80 \%$ \\
\hline Total & $8,086.00$ & $29.20 \%$ & $10,157.10$ & $31.60 \%$ & $14,018.40$ & $32.90 \%$ \\
\hline
\end{tabular}

Source: Author's compilation based on budget speeches 2011-2013.

\subsection{From patrimonial benefits to formal social protection}

The MMD government was often heavily criticised for its highly personalised and clientelistic state functioning (Erdmann and Simutanyi 2003). Typically in clientelistic relationships, politicians build up a pyramidal support structure in order to reinforce, monitor and control political support. Usually patrons on higher levels are wealthier than those on lower levels (Harland 2011). The prevalent tendency is that participants on all levels seek to ensure that they have as many resources as possible to deploy in the reaffirmation of the power structure (ibid). Hence people at the bottom of the pyramid usually constitute the poorest and least powerful participants (Stokes et al. 2013). The problem is clear: the clientelistic distribution of resources generally favours the 'better off' and is disadvantageous for the poorest in the society. Mason and Ricker-Gilbert (2013) argue that the clientelistic distribution of benefits under the MMD is well illustrated by the Farmers Input Support Programme (FISP). The budget allocations for the FISP were characterised by several changes expanding the programme in a pattern which suggest that the programme was being utilised to reward the rural MMD support base that was overwhelmingly comprised of rural farmers (ibid; Chapoto 2012). Estimates by the World Bank (2013:45) calculate that around $88 \%$ of the beneficiaries of the FISP were mid- or large-scale ('better-off') farmers and this was because the preconditions for enrolment - to grow $0.5 \mathrm{~h}$ of maize or to pay the share of the input package - could not easily be fulfilled by small-scale (poorer) farmers.

Further, formal social protection targeting the poor and vulnerable remained limited under the MMD government. This can be illustrated in regard to Zambia's social cash transfer schemes. Targeting of these programmes is based on politically neutral and objective criteria that focus on extremely poor households (equal to the lowest levels of the patrimonial support base) (GRZ 2012b). Furthermore, recipients are enrolled on a middle- to long-term perspective with formalised and rational graduation criteria (ibid). Moreover, the programmes are strongly supported by Cooperating Partners that strengthens oversight and monitoring and evaluation systems (ibid.). Hence, the way social cash transfers are implemented limits the utilisation of the programme as patrimonial benefit by high ranking politicians. It is not surprising that under the MMD, these programmes remained strongly donor-driven and limited in scope and outreach (Devereux and White 2010; Habasonda 2009; Schüring and Lawson-McDowall 2011). In 2011 the MMD allocated KR50 million (US\$9.6 million) to social cash transfers. This represents only $0.23 \%$ of total public expenditure. Further, the MMD committed to implement cash transfers in only 15 districts by 2015 (GRZ 2012b). This covers only less than $10 \%$ of the extreme poor in Zambia (World Bank 2013:59) ${ }^{32}$.

The PF government, on the other hand has appeared to shift towards more formal distribution of benefits. For instance, the PF has initiated several reforms of the FISP

32 This is calculated assuming perfect targeting and five people per household (World Bank 2013). 
programme, which some see as an effort to limit the use of the FISP as patrimonial benefit. ${ }^{33}$ Therefore, the PF has reduced the subsidy on the fertiliser and limited its distribution. Farmers now pay double for a bag of fertiliser and can only buy four instead of eight $50 \mathrm{~kg}$ bags of fertilisers (Bhalla 2013). The PF has also introduced an E-voucher system in order to increase accountability and transparency in the programme (Lusaka Times 2013). This aims to address some of the 'problems' that were previously seen as dogging the programme (World Bank 2013: 44). The reform of the FISP signals a break with the practices of the MMD government as the reformed programme widens the target to a large group regardless of their political affiliation. It also strengthens the application of rational targeting criteria and implements a more meaningful monitoring system.

Furthermore, the PF increased the budget for social cash transfer schemes substantially: from KR55 million (US\$10.6 million) in 2012 to KR72.1 million (US\$13.8 million) in 2013 and even KR199.2 million (US\$38.1 million) in 2014. Hence, the PF more than doubled the budget allocation for social cash transfers from 2013 to 2014. They also initiated the scale up of the programme from 15 districts (by 2015, as originally agreed in the Joint Financing Agreement) to 31 districts. ${ }^{34}$ The registration process for recipients was undertaken in early 2014. ${ }^{35}$ Moreover, in 2014 the PF government intended to further 'scale up the [funding] contribution to the Cash Transfer Scheme by over 700\%' (KPMG Zambia 2013: 11).

This section has looked at the supply side of social protection under the MMD and PF government. It has been argued that under the MMD formal social protection was heavily donor-driven. Social cash transfer schemes reflected direct donor interest and remained small in scope and outreach; while the FISP was utilised as benefits to reward the patrimonial support base of the MMD and received more support.

The PF government has taken more vigorous steps towards fostering the formal social protection agenda by beginning to develop a social protection policy (rights-based entitlement to social protection) and aligning the Sixth National Development Plan to the parties aspiration to shift more benefits to the extreme poor and vulnerable. The PF also created more fiscal space for social protection targeting of the extreme poor by abolishing market-intervention such as the fuel and maize miller subsidy. In order to mitigate the adverse effects of the policy change on the extreme poor and vulnerable the PF has increased social sector spending. In particular formal social protection such as social cash transfers have seen an immense budget increase under the PF. Further, former patrimonial social protection programmes have been reformed to more formal programmes by improving the transparency of these programmes. In sum, the section has revealed that the PF government, although it has the urban poor as one of its core constituencies, implements policy changes which are not entirely leaning on this support base but rather focuses on the extreme poor and vulnerable in both urban and rural areas. It concludes that the PF has been changing the development policy arena in ways that modify domestic political structures in ways that may provide more rights-based social protection, especially for the extreme poor and vulnerable. 


\section{Conclusion}

This paper has examined whether Zambia's PF-led government has been reforming the social protection sector in ways that shift more benefits to the extreme poor and vulnerable. The analysis of demand and supply of social protection in Zambia reveals that the PF has modified domestic political structures in ways that may facilitate the provision of rights-based social protection for the extreme poor and vulnerable, although the demand for it has been weak. It has been argued that the extreme poor and vulnerable, especially in rural areas, have only limited opportunities to voice their needs or pressure the government to respond to their demands due to the clientelistic state-society functioning and limited political leverage of civil society organisations or international donors in the social protection sector. Therefore it is concluded that the changes in the social protection sector in Zambia under the PF have been supply-, rather than demand-driven.

So far, the PF has not particularly employed a strategy to reward its support base; instead it has demonstrated commitment to formal social protection for the poor and vulnerable. The PF government has taken steps towards the development of a social protection policy that constitutes the main policy framework for a legal rights-based entitlement. The PF has also removed large-scale subsidies which were implemented by the MMD government, restricting the fiscal space for social spending. Furthermore, the PF has also reformed programmes which were used substantially to reinforce patriarchal connections to rural supporters of the MMD. The PF has also been scaling up social cash transfer programmes, that count as formal benefits as they target the extreme poor and vulnerable in rural areas, according to formal targeting criteria and strong oversight by donors. In the long run, this can undermine the influence of the middlemen and strengthen the demands by people at grassroots level as recipients who previously expected clientelistic rewards may begin to assume basic social rights.

But the absence of the expressions of demands for formal social protection may jeopardise the efforts taken to further pro-poor formal social protection in the long-run, as it hedges on the government's motivation to sustain the supply of social protection. In the absence of any organisations to hold the government accountable or expression of demands for rights-based and formal social protection for the poor and vulnerable, the reform is susceptible to political pressures. The PF could easily give up on social protection if it does not deliver the expected votes and return to previous programmes in exchange for votes (clientelism). Hence there is the danger that over time the government will stop supporting formal programmes and fall back into old patterns to gain support in rural areas by employing patrimonial strategies. Therefore, persistent clientelist state-society and weak civil society organisations are seen as main obstacles to sustain the provision of formal social protection for the extreme poor and vulnerable in the long run. Citizen participation at grassroots level and the promotion of transparency appear crucial to ensure that social protection for the extreme poor and vulnerable is procured and is sustained. 


\section{References}

Acemoglu, D.; Chaves, I.N.; Osafo-Kwaako, P. and Robinson J.A. (2013) Indirect Rule and State Weakness in Africa: Sierra Leone in Comparative Perspective, NBER Working Paper 20092, Cambridge: National Bureau of Economic Research (NBER)

Baldwin, K. (2013) 'Why Vote with the Chief? Political Connections and Public Goods Provision in Zambia', American Journal of Political Science 57: 794-809

Banful, A.B. (2010) 'Old Problems in the New Solutions? Politically Motivated Allocation of Program Benefits and the "New" Fertilizer Subsidies', World Development 39.7: 116676

Barrientos A. and Pellissery S. (2012) Delivering Effective Social Assistance: Does Politics Matter?, ESID Working Paper 09, Manchester: Effective States and Inclusive Development Research Centre (ESID)

Barrientos, A.; Hickey, S.; Simutanyi, N. and Wood, D. (2005) Report of Study on Drivers of Change for a National Social Protection Scheme in Zambia, Report undertaken for DFID, Lusaka: DFID Zambia

Bhalla, J. (2013) Maize Dependency and Agricultural Subsidies in Zambia: In Conversation with Rhoda Mofya-Mukuka, 11 July 2013, London: Africa Research Institute (ARI), www. africaresearchinstitute.org/blog/agricultural-subsidies-in-zambia/ (accessed date 26 June 2014)

Chabal, P. and Daloz, J.-P. (1999) Africa Works: Disorder as Political Instrument, Oxford: James Currey

Chapoto, A. (2012) The Political Economy of Food Price Policy: The Case of Zambia, UNUWIDER Working Paper 2012/100, Helsinki: United Nations University-World Institute for Development Economics Research (UNU-WIDER)

Cheeseman, N. and Hinfelaar, M. (2009) 'Parties, Platforms, and Political Mobilization: The Zambian Presidential Election of 2008', African Affairs 109.434: 51-76

Cheeseman, N. and Larmer, M. (2013) 'Ethnopopulism in Africa: Opposition Mobilization in Diverse and Unequal Societies', Democratization 2013: 1-29

Cheeseman, N. and Paget, D. (2011) Programmatic Parties, Stockholm: International Institute for Democracy and Electoral Assistance

CSO (2011) Living Conditions Monitoring Survey Report 2006 and 2010, Lusaka: Central Statistical Office (CSO)

CSO (2003) Migration and Urbanization: 2000 Census Report, Lusaka: Central Statistical Office (CSO)

CUTS International (2013) Understanding the Impact of the Removal of Fuel Subsidies on the Zambian Economy. A Case Study of Lusaka and Western Provinces, Lusaka: CUTS International 
De Haan, A.; Holland, J. and Kanji, N. (2002) 'Social Funds: An Effective Instrument to Support Local Action for Poverty Reduction?', Journal of International Development 14: $643-52$

Devereux, S. and McGregor, J.A. (2014) 'Transforming Social Protection: Human Wellbeing and Social Justice', European Journal of Development Research 26: 296-310

Devereux, S. and Sabates-Wheeler, R. (2004) Transformative Social Protection, IDS Working Paper 232, Brighton: IDS

Devereux S. and White, P. (2010) 'Social Protection in Africa: Evidence, Politics and Rights', Poverty and Public Policy 2.3: 53-77

DFID (2012) DFID’s Programme in Zambia. Fifth Report of Session 2012-13, London: The Stationery Office Limited

Duncan, A.; Macmillan, H. and Simutanyi, N. (2003) Zambia Drivers of Pro-poor Change: An Overview, Oxford: Oxford Policy Management (OPM)

Electoral Commission of Zambia (2011) 2011 Presidential Election Results, Public Notice, Lusaka: Electoral Commission of Zambia, 28 September 2011

Erdmann, G. and Simutanyi, N. (2003) Democratic Transition and Consolidation in Africa:

Transition in Zambia: The Hybridisation of the Third Republic, Occasional Papers 2003, Lilongwe: Konrad Adenauer Foundation

Freedom House (2013) Zambia, www.freedomhouse.org/report/freedom-world/2013/zambia (accessed 18 August 2013)

Gaventa, J. (2004) 'Towards Participatory Governance: Assessing the Transformative Possibilities', in S. Hickey and G. Mohan (eds), Participation: From Tyranny toTransformation, London: Zed Books: 25-41

Goetz, A.M. and Gaventa, J. (2001) Bringing Citizen Voice and Client Focus into Service Delivery, IDS Working Paper 138, Brighton: IDS

GRZ, Government of the Republic of Zambia (2013) Draft revised Sixth National Development Plan 2013-2016, stakeholder consultation, Lusaka: GRZ, August 2013

GRZ, Government of the Republic of Zambia (2012a) 2013 Budget Address by Hon. Alexander B. Chikwanda, MP, Minister of Finance, Lusaka: GRZ

GRZ, Government of the Republic of Zambia (2012b) Joint Financing Arrangement between the Ministry of Community Development, Mother and Child Health, the Ministry of Labour and the members of the Social Protection Cooperating Partners Group, Lusaka: GRZ

Habasonda, L.M. (2009) Political Economy of Cash Transfers in Zambia, report, London: Overseas Development Institute

Harland, C. (2014) 'Can the Expansion of Social Protection bring about Social Transformation in African Countries? The Case of Zambia', European Journal of Development Research 26.3: 370-86 
Harland, C. (2011) 'Can the Expansion of Social Protection bring about Social Transformation in African Countries? The Case of Zambia', International Conference: 'Social Protection for Social Justice', Brighton: Institute of Development Studies, 13-15 April 2011

Helle, A. and Rakner, L. (2012) The Interplay between Poverty and Electoral Authoritarianism: Poverty and Political Mobilization in Zambia and Uganda, CMI Working Paper 2012: 3, Bergen: Chr. Michelsen Institute

Hickey, S. (2007) Conceptualising the Politics of Social Protection in Africa, Working Paper 4, Manchester: Brooks World Poverty Institute (BWPI)

HLPE (2012) Social Protection for Food Security. A Report by the High Level Panel of Experts on Food Security and Nutrition of the Committee on World Food Security, Rome: HLPE

Jackson, C.; Butters, S.; Byambaa, E.; Davies, M. and Perkins, N. (2011) Lessons from Social Protection Programme Implementation in Kenya, Zambia and Mongolia, IDS Research Report 69, Brighton: IDS

Jakusch, M. and Naumann, H. (2011) Change of Power in Zambia - A Step Towards More Democracy, report on the elections of September 2011, Lusaka: Friedrich Ebert Foundation (FES)

Kitschelt, H. and Wilkinson, S. I. (2007) Patrons, Clients and Policies: Patterns of Democratic Accountability and Political Competition, New York: Cambridge University Press

KPMG Zambia (2013) 2014 Budget Highlights, 2014 Budget Guide, Lusaka: KPMG Zambia

Kuteya, A.N. and Jayne, T.S. (2012) Is the Government of Zambia's Subsidy to Maize Millers Benefiting Consumers?, IAPRI Working Paper 67, Lusaka: Indaba Agricultural Policy Research Institute (IAPRI)

Kuteya and Sitko (2014) 'Did the Removal of Consumer Subsidies in 2013 Lead to Higher Mealie-meal Prices?', IAPRI High Level Meeting, Siavonga: Indaba Agricultural Policy Research Institute (IAPRI), 7 March 2014

Lusaka Times (2013) 'Government has Not Done Away with the Farmer Input Support Programme', 18th June 2013, Lusaka: Lusaka Times, www.lusakatimes.com/2013/06/18/government-has-not-done-away-with-the-farmerinput-support-programme/ (accessed date 26 May 2014)

Magaloni, B. (2006) Voting for Autocracy: Hegemonic Party Survival and its Demise in Mexico, Cambridge: Cambridge University Press

Mamdani M. (1996) Citizen and Subject: Contemporary Africa and the Legacy of Late Colonialism, Princeton: Princeton University Press

Manor, J. (1999) 'Civil Society and Governance', Concept Paper, Brighton: IDS

Mason, N.M. and Ricker-Gilbert, J. (2013) 'Disrupting Demand for Commercial Seed: Input Subsidies in Malawi and Zambia', World Development 45: 75-91 
Motsamai, D. (2013) By-elections Galore in Zambia: Is Parliamentary Democracy Under Threat?, 5 July 2013, Pretoria: Institute for Security Studies (ISS),

www.issafrica.org/iss-today/by-elections-galore-in-zambia-is-parliamentary-democracyunder-threat (accessed date 15 June 2014)

Munro, L. (2007) Risks, Rights, and Needs: Compatible or Contradictory Bases for Social Protection?, Working Paper 7, Manchester: Brooks World Poverty Institute (BWPI)

Nino-Zarazua M.; Barrientos, A.; Hickey, S. and Hulme, D. (2011) 'Social Protection in SubSaharan Africa: Getting the Politics Right', World Development 40.1: 163-76

Ochieng' Opalo K. (2012) 'African Elections: Two Divergent Trends', Journal of Democracy 23.3: 80-93

Pelham, L. (2007) The Politics Behind the Non-contributory Old Age Social Pensions in Lesotho, Namibia and South Africa, CPRC Working Paper 83, Manchester: Chronic Poverty Research Centre (CPRC)

Petrauskis, C. (2007) Investing Directly in the Poor: A Demand for Social Protection in Zambia, Lusaka: Jesuit Centre for Theological Reflection

PF (2011) Patriotic Front 2011-2016 Manifesto, Lusaka: Patriotic Front (PF)

Prizzon, A. (2013) The Age of Choice: Zambia in the New Aid Landscape, research report, London: Overseas Development Institute (ODI)

Rakner, L. (2012) Foreign Aid and Democratic Consolidation in Zambia, UNU-WIDER Working Paper 2012/16, Bergen: United Nations University-World Institute for Development Economics Research (UNU-WIDER)

Rakner, L. and Van de Walle, N. (2009) 'Opposition Weakness in Africa', Journal of Democracy 20.3: 108-121

Resnick, D. (2010) Populist Strategies in African Democracies, UNU-WIDER Working Paper 114, Helsinki: United Nations University-World Institute for Development Economics Research (UNU-WIDER)

Schüring, E. and Lawson-McDowall, J. (2011) 'Social Protection in Zambia - Whose Politics?', IDS Bulletin 42.6: 21-7

Statehouse (2013) President Sata Assures Zambians, press release 15 June 2013, Lusaka: Statehouse, www.statehouse.gov.zm/en/president-sata-assures-zambians/ (5 August 2013)

Stokes, S.C.; Dunning, T.; Nasareno, M. and Brusco, V. (2013) Brokers, Voters, and Clientelism: The Puzzle of Distributive Politics, Cambridge: Cambridge University Press

Van Donge, J.K. (1998) 'Reflections on Donors, Opposition and Popular Will in the 1996 Zambian General Elections', Journal of Modern African Studies 36: 71-99

Weber, M. (1946) From Max Weber: Essays in Sociology, with an introduction by H.H Gerth and C. Wright Mills, New York: Oxford University Press

World Bank (2013) Using Social Safety Nets to Accelerate Poverty Reduction and Share Prosperity in Zambia, Washington DC: World Bank 
World Bank (2007) Zambia Poverty and Vulnerability Assessment, Washington DC: World Bank

Zambian Economist (2014) Draft Constitution of Zambia, 24 October 2014, www.zambianeconomist.com/2014/10/draft-constitution-of-zambia.html (accessed date 4 February 2015)

Zambian Watchdog (2013) With the Biggest Cabinet in Africa, Zambia to Remove All Subsidies for the Poor, press article, 13 May 2013, Lusaka: Zambian Watchdog, www.zambianwatchdog.com/with-the-biggest-cabinet-in-africa-zambia-to-remove-allsubsidies-for-the-poor/ (accessed date 15 August 2013) 